УДК 340.12:37.091.212:004

Юркевич Олена Миколаївна

доктор філософських наук, професор, професорка кафедри філософії

Національний юридичний університету імені Ярослава Мудрого, м. Харків, Україна.

ORCID ID 0000-0002-4023-4624

olenayurkevych@ukr.net

Павленко Жанна Олександрівна

кандидат юридичних наук, доцент, доцентка кафедри філософії

Національний юридичний університету імені Ярослава Мудрого, м. Харків, Україна.

ORCID ID 0000-0001-6408-4299

j1967@ukr.net

\title{
ТЕСТУВАННЯ ЗАГАЛЬНОЇ НАВЧАЛЬНОЇ ПРАВНИЧОЇ КОМПЕТЕНТНОСТІ: ЛОГІКО-МЕТОДОЛОГІЧНИЙ ІНСТРУМЕНТАРІЙ ТА ЕЛЕКТРОННИЙ КУРС ДЛЯ ПІДГОТОВКИ ДО ВСТУПНОГО ВИПРОБУВАННЯ
}

\begin{abstract}
Анотація. У статті досліджується використання логічного знання як методологічного інструментарію для побудови та вирішення тестів загальної навчальної правничої компетентності (ТЗНПК), що впроваджені у вищу юридичну освіту для відбору вступників на магістерські програми правничого спрямування. Уперше в Україні, відповідно до вимог сучасного суспільства, на базі платформи MOODLE створено та впроваджено в навчання електронний курс «Практична логіка: тренінг інтелектуальних здібностей» для підготовки до вступних випробувань на магістерські програми за спеціальністю 081 «Право». У ньому запропоновано узагальнення логічної методології і методики вирішення тестових завдань згідно 3 їх типологізацією, а також переосмислено практичне значення логіки для успішного проходження тестування за рівнями сформованості в учасників загальної навчальної правничої компетентності. Презентовані результати науково-практичних досліджень, що викладені в авторському посібнику «Підготовка до складання ТЗНПК в завданнях та рішеннях: логічний підхід». За принципами розумності права визначена специфіка використання логічних форм і методів, що впроваджуються в юридичній методології, їх необхідність як інструментарію в правознавчій аналітиці та юридичній практиці. Зроблені висновки щодо значення логічної культури для успішного проходження ТЗНПК, необхідності переоцінки програм логічної освіти у вишах та подальшого розвитку логічного знання у зв'язку з визначеними загальними інтелектуальними компетентностями юриста. У результаті нашого дослідження було доведено, що електронні курси на базі платформи MOODLE позитивно впливають на оволодіння студентами логічним інструментарієм для розв'язання ТЗНПК і мають потенційну освітню можливість як ефективний засіб для формування професійної компетентності майбутніх магістрів права. Подальший розвиток освітянських інформаційних технологій автори пов'язують із поглибленням усвідомлення взаємодії логічних і юридичних форм, поширенням логічної освіти, незмінним упровадженням нових інформаційних технологій в освітній процес, постійним зростанням актуальності розумової праці в суспільстві.
\end{abstract}

Ключові слова: інформаційні технології в юридичній освіті; електронне навчання; електронний курс на базі платформи MOODLE; TЗНПК (тест загальної навчальної правничої компетентності); логічна методологія.

\section{1. ВСТУП}

Постанова проблеми. Сучасній цивілізації притаманний все більш глибокий поділ праці, рольова взаємодія, що регулюється системою управління, яка поступово формалізується та ускладняється. Такі характеристики свідчать про зростання раціональності у свідомій площині соціального життя, що визначає рівень цивілізованості суспільства в цілому. Цьому рівню відповідає й сучасне європейське 
право. Європейський правовий простір формується з участю України як нового члена, i це потребує розвитку методології. Серед діючого методологічного інструментарію одним із найважливіших $є$ логічний. Сучасний аргентинський дослідник 3 логіки i філософії права Є. В. Булигін зазначав, що «в період з IV ст. до н. е. по XIX ст. н. е., тобто протягом більш ніж двох тисячоліть, саме логіка здійснювала вплив на правове мислення. В основі цього впливу знаходився Аристотель з його теорією дедуктивного міркування (силогізму) і теорією науки (аксіоматичною системою), які мали дуже глибокий вплив на мислення взагалі та на правове мислення зокрема» [1, с. 12]. У сучасному світі цей вплив поглиблюється.

Логіка постає як методологія, що використовується для впровадження принципу розумності права. Походження визначення принципу розумності права пов'язане з англоамериканським правом, де він почав розроблятись у значенні здатності людини свідомо досягати своїх інтересів у суспільстві, виходячи з власних інтелектуальних можливостей. Поняття розумності орієнтовано щонайменше на середній рівень розвитку людського інтелекту. Гарантований розвиток розумності права пов'язаний з необхідністю постійного вимірювання рівня інтелектуального розвитку фахівців-юристів. Таке вимірювання стало важливим сучасним завданням вищої юридичної освіти.

Знання логіки важливе нарівні із знанням юридичних законів. Це відзначають самі юристи. Логіка має методологічне значення як для правознавства, так і для законодавчої та правозастосовної практик, де фахівці використовують досконалі форми, найсильніші і найефективніші логічні прийоми, що необхідно для права 3 погляду його соціального значення.

У цьому аспекті правильною буде постанова питання щодо дослідження логічного знання як методологічного інструментарію для побудови тестів загальної правничої компетентності (далі ТЗНПК) з метою отримання висновків стосовно вимог до певного рівня інтелектуального розвитку в правничій професії та використання можливостей нових технологій в освіті для досягнення цього рівня.

Аналіз останніх досліджень і публікацій. Питанням розробки концепції, програми і специфікації ТЗНПК та вивчення зарубіжного досвіду тестування вступників до закладів вищої освіти, зокрема правничих шкіл, і доцільності його впровадження в юридичну освіту в нашій країні була присвячена низка праць. Окреслена проблематика знаходить своє відображення в працях таких вітчизняних науковців, як-от: В. Брюховецький [2], В. Бугров [3], Т. Вакуленко [4], О. Вашуленко, В. Горох [5], О. Кирієнко, В. Ковальчук, С. Ломакович [6], А. Миляник, В. Пузирьов, С. Раков [7] - [9], Л. Рябовол [10], В. Терещенко [11] та ін. Дослідженню логічного знання як методологічного інструментарію для побудови ТЗНПК присвячені праці I. Матюшиної, Ж. Павленко [12], О. Тягла [13], О. Щербини [14], О. Юркевич [15] та ін. Дослідженню проблем інтелектуалізації суспільства, створення й упровадження нових технологій, що базуються на ефективному використанні головного стратегічного ресурсу суспільства - знань, у нашій країні, була присвячена низка праць соціальнофілософського спрямування, логіко-гносеологічного, філософсько-правового, когнітивно-інформаційного. Зокрема цією проблемою займались: В. Андрущенко, I. Бойченко, О. Данильян, О. Дзьобань, А. Конверський, С. Кримський, В. Кушерець, А. Уйомов та ін. Продуктивна цінність знання в розвитку суспільства та його вплив на особу стали предметом аналізу багатьох учених за кордоном, зокрема інформаційнотехнологічного напряму: І. Міцури, С. Осуги, К. Шенона, І. Харукі, та представників теорії постіндустріального й інформаційного суспільства: Д. Белла, Й. Масуди, Е. Тофлера, Ф. Фукуями та ін. В умовах становлення та розвитку цифрового суспільства одним з головних показників економічної стабільності країни є отримання якісної вищої освіти, що забезпечується шляхом упровадження в освітній процес новітніх 
інформаційних технологій, зокрема використання можливостей електронних курсів на базі платформи MOODLE.

У цілому можна зауважити, що системне наукове осмислення складної, місткої і багатоаспектної проблеми дослідження логічного знання як методологічного інструментарію для побудови ТЗНПК знаходиться лише на початковому етапі.

Метою статті $є$ розгляд окремих аспектів використання логічної методології $\mathrm{i}$ методики вирішення ТЗНПК, технологічного підходу до логічного знання для створення сучасного електронного курсу, що відповідає вимогам сьогодення та сприяє переосмисленню практичного значення логіки для юристів.

\section{2. ТЕОРЕТИЧНІ ОСНОВИ І МЕТОДИ}

Логічне знання, особливо правила i закони логіки, критерії істинності у формальній логіці стали еталоном як платформа, що передує утворенню норм права і $\epsilon$ номінальною «рамкою» для усіх юридичних форм у цілому. Традиційно до логічних методів належать основні прийоми пізнання - аналіз і синтез; логічні методи отримання висновку - дедукція, індукція та аналогія, які в сучасних дослідженнях ще доповнюються методом абдукції; методи абстрагування та ін. Логічні методи використовуються для моделювання в царині юриспруденції, особливо для юридичної аргументації. Логічна форма класичного визначення постає основою дифінітивної норми. Логічною формою судового рішення $\epsilon$ modus Barbara простого категоричного силогізму, який називають судовим модусом. Процедура кваліфікації правопорушення має логічну форму modus ponens умовно-категоричного силогізму, його часто-густо називають юридичним силогізмом, і цей модус стає стрижнем так званого «німецького стилю» в європейській юридичній методології правозастосування. Так, Р. Циппеліус, пояснюючи субсумцію, пише: «Коли кажуть, що конкретна ситуація кваліфікована відповідно до абстрактного юридичного складу, встановленого законом, то мають на увазі юридичні міркування, які мають вигляд логічного висновку (modus ponens)» [16, c. 156-57]. Modus tollens умовно-категоричного силогізму є логічною формою як формально-логічний стандарт правової норми і т. ін.

Таке співвідношення логічних і юридичних форм і норм їх побудови $є$ стійким $\mathrm{i}$ дозволяє продовжити дослідження з розширенням методологічного значення логічного знання разом з методологію тестування для юристів.

Освітні навчальні програми з логіки для юристів також передбачають, що логічні знання $\epsilon$ необхідною складовою загальних компетентностей фахівців права. Серед таких інтелектуальних компетентностей у сучасній вищій юридичній освіті виділяють три характеристики: аналітичне мислення, логічне мислення і критичне мислення.

Під аналітичним мисленням розуміють здатність працювати з великими обсягами інформації, до яких необхідно застосовувати прийоми розподілу матеріалу на частини і подальше поступове дослідження кожної складової.

Логічне мислення - це здатність мислити правильно, тобто визначено, послідовно i аргументовано, не допускаючи протиріч у своїх міркуваннях, а також викривати логічні помилки. Його особливістю $є$ вміння абстрагуватись від конкретного та узагальнювати суттєве в предметі, а також, визначаючи підстави, робити висновки. Тобто воно визначає здатність особи аналізувати інформацію на відповідність законам i методам побудови коректних міркувань.

Критичне мислення є специфічним видом рефлексії, який грунтується на знанні науки логіки і відповідної предметної сфери, стосовно якої конструюється міркування. Критичне мислення допомагає правильно орієнтуватися в постійно зростаючих потоках професійної інформації й знаходити в них підстави для оптимальних рішень. Повний 
цикл критичного мислення містить чотири взаємообумовлених фази: аналіз - розуміння - оцінку - критику [13, с. 17]. Це особливе мислення, яке має на меті оцінку ідей.

Серед новітніх вимог до логічної освіти майбутніх юристів визначаються навички комплексного розв'язання проблем (з умінням комбінувати логічні форми, їх елементи), креативність (з усвідомленням логічних особливостей імовірних висновків), уміння самостійно приймати рішення на основі правильно отриманих висновків, вести переговори (керуючись комунікативною логікою), гнучкість у міркуванні (як здатність формувати обгрунтування та отримувати висновки декількома способами) тощо.

Усвідомлення значення логічного знання для фахівців права на сучасному етапі розвитку українського суспільства викликало потребу введення з 2017 року обов'язкового тесту (ТЗНПК) , який вимірює ступінь розвитку вищевказаних компетентностей, для студентів-юристів при вступі до магістратури [17, с. 17-18]. Логічні знання є єдиною теоретико-методологічною основою алгоритмів побудови ТЗНПК для всіх трьох характеристик інтелектуальних компетентностей у сучасній вищій юридичній освіті, зважаючи на їх логічний взаємозв'язок. 3 логічного погляду аналітичне, логічне і критичне мислення як різні загальні компетентності є різними аспектами одного й того ж правильного мислення, що має здійснюватись за логічними критеріями істинності.

Упровадження стандартизованих освітніх вимірювань у вищій школі та аналіз комплексних даних надають нові можливості в управлінні якістю освіти [18] - [21], що максимально потребує вироблення у студентів-юристів навичок критичного аналізу, розуміння, оцінки і критики аргументації деякого висновку з тієї чи іншої досліджуваної проблеми.

Структура ТЗНПК складається 3 трьох секцій: аналітичне, логічне та критичне мислення. Мета тестових завдань секції «Аналітичне мислення» - виміряти здатність студента юриста аналізувати дані й правила оперування ними 3 метою визначення, що $є$ істинним або що може бути істинним. Мета тестових завдань секції «Логічне мислення» - виміряти здатність студента аналізувати, оцінювати, доповнювати судження, міркування, аргументацію, викладені природною мовою. Мета тестових завдань секції «Критичне мислення» - виміряти здатність вступника ефективно застосовувати навички критичного мислення при роботі з великими за обсягом і складними за змістом текстами різної тематики [17, с. 21-22]. Результати, які отримують юристи як при професійному тестуванні загальних здібностей, так і при проходженні ТЗНПК студентами по всій країні невисокі: максимальна оцінка (ТЗНПК) складає 30 балів, фаховою комісією встановлений пороговий бал на рівні 8 балів при пороговому значенні сліпого вгадування 6 балів. Зокрема статистичний розрахунок 2018 р. показав, що близько 12-13 \% тих, хто давав відповіді «всліпу», подолали пороговий бал 8 [22, с. 10].

\section{3. РЕЗУЛЬТАТИ ДОСЛІДЖЕННЯ}

Аналіз результатів ТЗНПК дає можливість стверджувати, що рівень культури мислення студентів юридичних закладів вищої освіти необхідно вдосконалювати. Тому перед логіками постало завдання знайти ефективні методики використання теоретично обгрунтованих навичок аналізу, розуміння, оцінки і критики проблемних міркувань.

Першим кроком на цьому шляху $є$ формування навичок використання методу формалізації для кодування даних та оволодіння елементарними знаннями 3 формально-логічного погляду про поняття, методи їх визначення та перетворення, судження про них і структуру доказових міркувань. Для формалізації інформації в умовах завдань та у відповідях на тестові запитання необхідно використовувати мову логіки висловлювань. Для розв'язання деяких завдань необхідно формалізувати відповіді та використовувати найпростіші перетворення класичних формул. Усі 
завдання розв'язуються логічними методами з використанням таблиць, графіків, діаграм, елементарними обчисленнями тощо. В узагальненому вигляді етапи рішення завдань із секції «Аналітичне мислення» можна представити так: кодування інформації, 3 якої складаються умови завдання; кодування інформації, яка міститься в запитаннях до завдання; кодування інформації, яка належить до відповідей на тестові запитання; вибір найелементарнішого методу рішення конкретного завдання (відповідно до умов): за допомогою таблиць, графіків, діаграм Ейлера-Венна, алгебраїчним рівнянням тощо; надавання відповідей на запитання.

Логіко-структурний аналіз вербальних текстів розкриває логіку сенсу і може здійснюватись на різних ступенях «глибини». Це передбачає використання певного логічного інструментарію. Передусім при аналізі текстів необхідні знання з логічної mеорії аргументаціï. Так, у багатьох тестових завданнях ставиться питання щодо визначення елементів структури аргументації - тези, аргументів, демонстрації (обгрунтування). Тезу в завданнях часто позначають як «головну думку» тексту та пропонують вибрати із запропонованих відповідей таку, що містить відповідне судження (тезу) [12, с. 75]. Для вибору правильної відповіді необхідно використовувати закон тотожності, згідно з яким будь-яка думка в межах певного міркування має залишатись тотожною собі. Визначальною логічною характеристикою «головної думки» тексту буде їі обсяг, який має бути найширшим у тексті і поглинати обсяги інших понять [12, с. 76, 94, 100]. Протилежними за своєю методологією будуть завдання, у яких потрібно встановити антитезу або контраргументи [12, с. 85].

Ще одним важливим логічним інструментом для вирішення тестів щодо оцінки рівня критичного мислення $є$ знання про імплікацію. Імплікація - це причиннонаслідковий зв'язок між думками, який може бути в таких різних логічних формах, як-от: складні імплікативні судження, суто умовний силогізм, умовно-категоричний силогізм, умовно-розділовий силогізм та при обгрунтуванні доказовості аргументації або спростуванні. Узагальнені логічні знання про імплікацію є методом побудови тестових завдань певного типу, а також методом вирішення тих самих завдань [12, с.77]. Тобто логічна методологія є загальною як для авторів створених тестів, так i для тих, хто їх вирішуе.

Наступним типом тестових завдань є такі, у яких містяться питання встановлення логічного значення істини і хиби. Для фахівця-юриста розрізнення істини і хиби, тобто логічно правильного і неправильного, а також дійсного і фальшивого $є$ значущою фаховою інтелектуальною рисою. Тому критерії логічної істинності $\epsilon$ універсальним методом логічної оцінки для всіх предметів думки [12, с. 80]. Типовими є також тестові завдання, у яких потрібно коректно порівняти, провести аналогію та визначити ступінь імовірності. Для проведення аналогії насамперед необхідно встановити суттєві ознаки предметів, що порівнюються, та визначити, яка з відповідей буде найбільш імовірною [12, с. 96, 98]. Список методологічних засобів можна продовжувати, але й цих прикладів достатньо для того, щоб зрозуміти значення логічного знання щодо побудови тестових завдань для визначення рівня розвитку інтелектуальних здібностей юристівбакалаврів, а також для їх вирішення.

Із метою впровадження в навчання сучасної інформаційної системи, що автоматизує процес підготовки користувачів до складання психометричного тесту, авторами статті на базі платформи MOODLE була створена база даних «Практична логіка: тренінг інтелектуальних здібностей» [23], призначена для підвищення ефективності навчального процесу за рахунок використання засобів новітніх інформаційних технологій. Ця база даних має на меті розвиток логічної культури мислення особи і розроблена 3 урахуванням стандартної структури тестів щодо визначення інтелектуальних здібностей. Вона містить спеціальні завдання та вправи на 
вдосконалення здібностей сприйняття, уваги, пам'яті, різних аспектів мисленнєвої діяльності. Інформація розміщена за такими змістовними блоками: 1. Аналіз числової інформації, логічні послідовності. 2. Аналогії, відновлення висловлювань. 3. Алгоритмізація суджень: рівнозначність, висновки шляхом трансформації, нормативність логічного слідування. 4. Логіко-структурний аналіз текстів.

Ресурсами бази даних $є$ програма дистанційного курсу «Практична логіка: тренінг інтелектуальних здібностей», яка дозволяє користувачу зорієнтуватись у тих основних питаннях, які відбивають його зміст і виносяться на поточний та підсумковий контроль, i теоретико-методичний матеріал для підготовки до психометричного тестування рівня інтелектуальних здібностей, який дозволяє користувачу курсу на належному рівні скласти навчальний або професійний тест. Активні елементи курсу мають новинний форум, який знаходиться в нульовому розділі курсу; практикум у формі тестових завдань для поточного контролю. Також авторами курсу складена база тестових завдань, які потім можуть використовуватись у різноманітних тестах. Тестування для підсумкового контролю 3 курсу, яке максимально наближено за структурою до навчальних або професійних тестів, містить три змістовних блоки із завданнями на логіко-аналітичне та критичне мислення.

\section{4. ВИСНОВКИ ТА ПЕРСПЕКТИВИ ПОДАЛЬШИХ ДОСЛІДЖЕНЬ}

Зміни в соціальній практиці поставили питання щодо термінової належної підготовки студентів і фахівців у сфері права до нових випробувань. Відповідь на це питання знаходиться в площині визначення ефективної методології та методики для підготовки правознавців до психометричного тестування.

Логіка за своїм призначенням є не лише універсальним методом конструювання нового знання. Вона є тією єдиною мовою, у термінах якої найбільш вірогідний давно очікуваний великий синтез математичних, природничих i гуманітарних наук. Викладання логіки з урахуванням сучасних вимог не може не враховувати нагальних змін у іiі розвитку й викладанні, перегляду їі місця в системі загальнонаукового знання. Тобто на часі переформатування програм 3 логіки і дисциплін логічного циклу в юридичних закладах вищої освіти, які до цього часу виконували нехарактерні для них функції початкової логічної освіти, та переорієнтація викладання цих дисциплін із суто теоретичних (в основному) на практичні аспекти. Крім того, при розробці нової програми підготовки значну увагу потрібно приділити методам навчання особи, яка готується до складання тестів, використання нею загальних знань і всіх технік економії часу. Тобто доцільним є додання до програми завдань, спрямованих на вдосконалення здібностей сприйняття, уваги, пам'яті, а саме вправ за таблицями Шульте, на аналіз числової інформації, відновлення логічних послідовностей, порівняння понять, зокрема аналогії, відновлення висловлювань. Головна увага при викладанні тем курсу має приділятися насамперед таким особливостям поведінки людини: послідовному i операціональному характеру формування інтелекту; комбінаторному, імовірнісному, інформаційному і поведінковому аспектам інтелектуальних дій особи; значному відсотку недедуктивних умовиводів у міркуваннях. Це дає можливість запропонувати єдиний алгоритм аналізу початкової інформації (засновків), яка дозволить розв'язувати як дедуктивні, так і недедуктивні завдання і наближена до тієї, що використовується як новачком, так і експертом у цій галузі.

Усі вищезазначені особливості вимагають по-новому викладати традиційну і символічну логіки із залученням можливостей, які надають сучасні освітні технології, подавати їх зміст у вигляді послідовно зв'язаних один з одним рівнів формування єдиного інтелекту і розширити зміст логіки як навчальної дисципліни такими розділами: аналіз, розуміння, оцінка аргументованого міркування, критика 
аргументації, прийняття рішень, подолання конфліктів тощо. Це дозволить залучити логіку до загального потоку сучасних гуманітарних і природничих досліджень, вивести iї на якісно новий рівень розвитку.

\section{СПИСОК ВИКОРИСТАНИХ ДЖЕРЕЛ}

[1] Е. В. Булыгин, «Логика и право», Правоведение, № 4 (309), с. 12-17, 2013.

[2] В. С. Брюховецький, О. В. Кирієнко, В. М. Ковальчук, «Дослідження ефективності реорганізаційних кроків у процедурі вступу до вищих навчальних закладів України на прикладі Києво-Могилянської академії», Вісник. Тестування і моніторинг в освіті, № 7, с. 23-31, 2011.

[3] В. А. Бугров, «Порівняльне дослідження вхідного рівня підготовленості студентів 1 курсу і результатів ЗНО», Вісник. Тестування і моніторинг в освіті, № 4, с. 13-15, 2011.

[4] Т. С. Вакуленко, «Світовий досвід використання тестів здатностей при вступі до ВНЗ», Вивчаємо українську мову та літературу: наук.-метод. журн., № 12 (304), квітень, с. 35-37, 2012.

[5] В. М. Терещенко, С. А. Раков, В. П. Горох, С. В. Ломакович, Т. С. Вакуленко, «Обгрунтування відповідей до завдань апробаційного ТЗПНК», ТІМО. Тестування і моніторинг в освіті, № 4-5, с. 3745, 2016.

[6] С. В. Ломакович, В. М. Терещенко, Т. О. Лук’янчук, В. С. Корнійчук, «Вербально-комунікативна компетентність особистості: виміри й вимірювання», Вісник. Тестування і моніторинг в освіті, № 1 , с. 4-15, 2011.

[7] С. А. Раков, О. П. Вашуленко, В. П. Горох, А. І. Миляник, В. В. Пузирьов, «Три виміри логікоматематичної компетентності», Вісник. Тестування і моніторинг в освіті, № 12, с. 7-16, 2009.

[8] С. Раков, В. Терещенко, «Впровадження тесту загальної навчальної правничої компетентності (ТЗНПК) як спосіб підвищення ефективності та справедливості відбору вступників на магістерські програми за спеціальностями 081 “Право”», Право України, № 10, с. 125, 2017.

[9] О. І. Ляшенко, С. А. Раков, «Тест загальної навчальної компетентності: основні засади і результати пілотування», Педагогіка і психологія, № 2, с. 27-35, 2012.

[10] Л. Т. Рябовол, «Тестування загальної навчальної правничої компетентності (ТЗНПК): деякі дискусійні аспекти проблеми», Часопис Київського університету права, 2018/2, с. 340-345, 2018.

[11] С. В. Ломакович, В. М. Терещенко, «Вербально-комунікативна складова загальної навчальної компетентності та ії вимірювання», Педагогіка і психологія. Вісник НАПН України, № 2 (75), с. 40-48, 2012.

[12] О. М. Юркевич, Ж. О. Павленко, Підготовка до складання ТЗНПК в завданнях та рішеннях: логічний niдxid: Навчальний посібник (Видання друге, доповнене та перероблене), Харків, Україна: Контраст, 2019.

[13] А. В. Тягло, Критическое мыпиение на основе элементарной логики. Харьков, Украина: ХНУ имени В.Н. Каразина, Издательский центр, 2001.

[14] О. Ю. Щербина, «Логічне моделювання та юридична аргументація», Вісник Київського національного університету імені Тараса Шевченка. Філософія. Політологія, Вип. 1, с. 50-53, 2014.

[15] О. М. Юркевич, Ж. О. Павленко, «Логіко-методологічні засади вимірювання рівня розвитку інтелектуальних здібностей» на Міжнар. наук. конф. Дні науки філософського факультету - 2017, Київ, 2017, с. 288-290.

[16] Р. Ціппеліус, Юридична методологія: Навчальний посібник, Чернівці, Україна: Рута, 2003.

[17] С. А. Раков, В. М. Терещенко, Тест загальної навчальної правничої компетентності (ТЗНПК) як блок єдиного фахового вступного випробування (СФВВ) у системі вступу на другий (магістерський) рівень вищої освіти за спеціальностями 081 «Право» та 293 «Міжнародне право». Інформаційні матеріали, Київ, 2019. [Електронний ресурс]. Доступно: https://mon.gov.ua/storage/app/media/vishcha-osvita/vstup2019/2019/09/njtznpkbukletrozshireniy2019ukr1.pdf. Дата звернення: Листоп. 04, 2019.

[18] М. Є. Скиба, С. Г. Костогриз, Г. В. Красильникова, Моніторинг якості навчального процесу у вищому закладі освіти : монографія, Хмельницький, Україна: ХНУ, 2009.

[19] В. П. Сергієнко, Н. В. Сорокіна, «Теоретичні та методичні засади моніторингу якості вищої освіти», Збірник наукових пращь Кам'янещь-Подільського національного університету ім. Івана Огієнка. Серія : Педагогічна, вип. 19, с. 119-124, 2013. [Електронний ресурс]. Доступно: http://nbuv.gov.ua/UJRN/znpkp_ped_2013_19_44. Дата звернення: Листоп. 04, 2019.

[20] Л. А. Марцева, «Тестування як фактор формування професійно важливих якостей майбутніх фахівців», Науковий часопис Національного педагогічного університету імені М. П. Драгоманова. Серія 5: Педагогічні науки : реалії та перспективи : зб. наук. праць, вип. 43, с. 131-138, 2013.

[21] В. А. Мізюк, О. В. Коваленко, «Про один із підходів до комп'ютерного тестування навчальних досягнень студентів», Науковий вісник Ізмайльського державного гуманітарного університету. Серія: 
Педагогічні науки, вип. 33, с. 120-125. [Електронний ресурс]. Доступно: http://dspace.idgu.edu.ua/jspui/bitstream/123456789/210/1/28.pdf. Дата звернення: Листоп. 04, 2019.

[22] С. О. Мудрук, Стандартизовані освітні вимірювання 2018 року у вищій юридичній освіті. Сдине фахове вступне випробування та Єдиний вступний іспит. Аналітичне дослідження, Київ, Україна: Baiтe, 2019. [Електронний ресурс]. Доступно: https://www.osce.org/uk/project-coordinator-inukraine/422930?download=true.

[23] О. М. Юркевич, Ж. О. Павленко, Г.В. Коваленко, «База даних «Практична логіка: тренінг інтелектуальних здібностей»»), Свідоцтво про реєстраџію авторського права на твір № 73545, Серп. 22, 2017 p. [Електронний ресурс]. Доступно: http://dl.nlu.edu.ua/course/view.php?id=34. Дата звернення: Листоп. 04, 2019.

Матеріал надійшов до редакиії 07.11.2019 p.

\title{
ТЕСТИРОВАНИЕ ОБЩЕОБРАЗОВАТЕЛЬНОЙ ЮРИДИЧЕСКОЙ КОМПЕТЕНТНОСТИ: ЛОГИКО-МЕТОДОЛОГИЧЕСКИЙ ИНСТРУМЕНТАРИЙ И ЭЛЕКТРОННЫЙ КУРС ДЛЯ ПОДГОТОВКИ К ВСТУПИТЕЛЬНОМУ ЭКЗАМЕНУ
}

\author{
Юркевич Елена Николаевна \\ доктор философских наук, профессор, профессор кафедры философии \\ Национальный юридический университет имени Ярослава Мудрого, г. Харьков, Украина \\ ORCID ID 0000-0002-4023-4624 \\ olenayurkevych@ukr.net
}

Павленко Жанна Александровна

кандидат юридических наук, доцент, доцент кафедры философии

Национальный юридический университет имени Ярослава Мудрого, г. Харьков, Украина

ORCID ID 0000-0001-6408-4299

j1967@ukr.net

\begin{abstract}
Аннотация. В статье исследуется использование логического знания как методологического инструментария для построения и решения тестов общеобразовательной юридической компетентности (ТОЮК), внедренной в высшее юридическое образование для отбора поступающих на магистерские программы юридического направления. Впервые в Украине в соответствии с требованиями современного общества на базе платформы MOODLE создан и внедрен в обучение электронный курс «Практическая логика: тренинг интеллектуальных способностей» для подготовки к вступительным экзаменам на магистерские программы по специальности 081 «Право». В нем предложено обобщение логической методологии и методики решения тестовых заданий в соответствии с их типологизацией, а также переосмыслено практическое значение логики для успешного прохождения тестирования по уровням сформированности у участников общеобразовательной юридической компетентности. Представлены результаты научнопрактических исследований, содержащиеся в авторском пособии «Подготовка к сдаче ТОУЮК в заданиях и решениях: логический подход». Опираясь на принцип разумности права, определена специфика использования логических форм и методов, которые внедряются в юридической методологии, их необходимость как инструментария в правоведческой аналитике и юридической практике. Сделаны выводы относительно значения логической культуры для успешного прохождения ТОЮК, необходимости переоценки программ логического образования в вузах и дальнейшего развития логического знания в связи с определенными общими интеллектуальными компетенциями юриста. В ходе нашего исследования было доказано, что электронные курсы на базе платформы MOODLE положительно влияют на овладение студентами логическим инструментарием для решения ТОЮК и имеют потенциальную образовательную возможность как эффективное средство для формирования профессиональной компетентности будущих магистров права. Дальнейшее развитие образовательных информационных технологий авторы связывают с углублением осознания взаимодействия логических и юридических форм, распространением логического образования, неизменным внедрением новых информационных технологий в образовательный процесс, постоянным ростом актуальности умственного труда в обществе.
\end{abstract}


Ключевые слова: информационные технологии в юридическом образовании; электронное обучение; электронный курс на базе платформы Moodle; ТОЮК (тест общеобразовательной юридической компетентности); логическая методология.

\title{
GENERAL EDUCATIONAL LEGAL COMPETENCY TESTS: LOGICAL- METHODOLOGICAL INSTRUMENTS AND E-COURSE FOR ENTRANCE TESTS PREPARATION
}

\author{
Olena M. Yurkevych \\ Doctor of Philosophy, Professor, Professor at the Department of Philosophy \\ Yaroslav Mudryi National Law University, Kharkiv, Ukraine \\ ORCID ID 0000-0002-4023-4624 \\ olenayurkevych@ukr.net
}

\section{Zhanna O. Pavlenko}

$\mathrm{PhD}$, Associate Professor, Associate Professor at the Department of Philosophy Yaroslav Mudryi National Law University, Kharkiv, Ukraine

ORCID ID 0000-0001-6408-4299

j1967@ukr.net

\begin{abstract}
The article explores the use of logical knowledge as a methodological toolkit for the construction and resolution of General Educational Legal Competency Tests (GELCT), which are implemented in higher legal education for the selection of applicants for masters programs in law. For the first time in Ukraine, in accordance with the requirements of modern society, on the basis of the MOODLE platform, an electronic course «Practical Logic: Training of Intellectual Abilities» was created and implemented for preparation for entrance tests for master's programs in specialty 081 «Law», which offers generalizations of the methodology and logic solution of test problems according to their typologization, rethinking the practical meaning of logic for successful passing of testing by levels of formation in participants of general training legal competence. The results of the scientific and practical researches contained in the author's manual «Preparation for the assembly of GELCT in tasks and decisions: a logical approach» are presented. Based on the principle of reasonableness of law, the specifics of the use of logical forms and methods implemented in the legal methodology, their necessity as tools in legal analytics and legal practice are defined. Conclusions have been made regarding the importance of logical culture for the successful passage of the GELCT, the need for reassessment of programs of logical education in higher education, and the further development of logical knowledge in relation to certain general intellectual competencies of the lawyer. As a result of our research, it has been proven that MOODLE-based e-courses have a positive impact on students' mastery of the logical tools for untying GELCT and have the potential educational opportunity as an effective means of shaping the professional competence of future masters of law. Further development of educational information technologies is associated with the deepening of the awareness of the interaction of logical and legal forms, the spread of logical education, the constant introduction of new information technologies in the educational process, the constant increase in the relevance of mental work in society.
\end{abstract}

Keywords: information technology in legal education; e-learning; an electronic course based on the Moodle platform; GELCT (General Educational Legal Competency Tests); logical methodology.

\section{REFERENCES (TRANSLATED AND TRANSLITERATED)}

[1] E. V. Bulyhin, «Logic and Law», Pravovedenye, № 4 (309), s. 12-17, 2013. (in Russian).

[2] V. S. Bryukhovets'kyy, O. V. Kyriyenko, V. M. Koval'chuk, «Investigation of the Effectiveness of Reorganization Steps in the Procedure of Admission to Higher Educational Institutions of Ukraine on the Example of Kyiv Mohyla Academy», Visnyk. Testuvannya i monitorynh v osviti, no. 7, pp. 23-31, 2011. (in Ukrainian).

[3] V. A. Buhrov, «Comparative Study of the Entry Level of Students' Preparedness of 1st year and the results of IEE», Visnyk. Testuvannya i monitorynh v osviti, no. 4, pp. 13-15, 2011. (in Ukrainian).

[4] T. S. Vakulenko, «The World Experience in Using Tests of Enrollment in Higher Education», Vyvchayemo ukrayins'ku movu ta literaturu: nauk.-metod. zhurn., no. 12 (304), pp. 35-37, 2012. (in Ukrainian). 
[5] V. M. Tereshchenko, S. A. Rakov, V. P. Horokh, S. V. Lomakovych, T. S. Vakulenko, «Substantiation of the answers to the tasks of the GLCT testing», TIMO. Testuvannya i monitorynh v osviti, no. $4-5$, pp. 37-45, 2016. (in Ukrainian).

[6] S. V. Lomakovych, V. M. Tereshchenko, T. O. Luk’yanchuk, V. S. Korniychuk, «Verbal-communicative competence of the individual: dimensions and measurements», Visnyk. Testuvannya i monitorynh v osviti, no. 1, pp. 4-15, 2011. (in Ukrainian).

[7] S. A. Rakov, O. P. Vashulenko, V. P. Horokh, A. I. Mylyanyk, V. V. Puzyr'ov, «Three Dimensions of Logic and Mathematical Competence», Visnyk. Testuvannya $i$ monitorynh v osviti, no. 12, pp. 7-16, 2009. (in Ukrainian).

[8] S. Rakov, V. Tereshchenko, «Implementation of the General Educational Legal Competency Tests (GELCT) as a Way to Increase the Fictitiousness and Fairness of Selection of Entrants for the Master's Programs in Specialties 081 «aw»», Pravo Ukrayiny, no.10, pp. 125, 2017. (in Ukrainian).

[9] O. I. Lyashenko, S. A. Rakov, «Test of General Educational Competence: basic principles and results of piloting», Pedahohika i psykholohiya, no. 2, pp. 27-35, 2012. (in Ukrainian).

[10] L. T. Ryabovol «General Educational Legal Competency Test (GELCT): Some Discussion Aspects of the Problem», Chasopys Kyyivs 'koho universytetu prava, 2018/2,pp. 340-345, 2018. (in Ukrainian).

[11] S. V. Lomakovych, V. M. Tereshchenko, «Verbal-communicative component of general educational competence and its measurement», Pedahohika i psykholohiya. Visnyk NAPN Ukrayiny, no. 2 (75), pp. 40-48, 2012. (in Ukrainian).

[12] O. M. Yurkevych, Zh. O. Pavlenko, Preparation for GELCT Assembly in Tasks and Solutions: A Logical Approach: A Textbook, Kharkiv, Ukrayina: Kontrast, 2019. (in Ukrainian).

[13] A. V. Tyahlo, Critical Thinking Based on Elementary Logic. Khar'kov, Ukrayna: KHNU imeni V.N. Karazina, Vydavnychyy tsentr, 2001. (in Russian).

[14] O. Yu. Shcherbyna, «Logical Modeling and Legal Argumentation», Visnyk Kyyivs'koho natsional'noho universytetu imeni Tarasa Shevchenka. Filosofiya. Politolohiya, Vyp. 1, pp. 50-53, 2014. (in Ukrainian).

[15] O. M. Yurkevych, ZH. O. Pavlenko, «Logical and methodological foundations of measuring the level of development of intellectual abilities». Days of Science of the Faculty of Philosophy International Conf. - 2017, Kyiv, 2017, pp. 288-290. (in Ukrainian).

[16] R. Tsippelius, Legal Methodology: A Textbook, Chernivtsi, Ukrayina: Ruta, 2003. (in Ukrainian).

[17] S. A. Rakov, V. M. Tereshchenko, Test of General Educational Legal Competency (GELCT) as a unit of unified professional entrance examination in the system of entry to the second (master's) level of higher education in specialties 081 "Law" and 293 International Law. Information materials, Kyiv, 2019. [Online]. Available: $\quad$ https://mon.gov.ua/storage/app/media/vishcha-osvita/vstup2019/2019/09/njtznpkbukletrozshireniy2019ukr1.pdf. Accessed on: Nov. 04, 2019. (in Ukrainian).

[18] M. Ye. Skyba, S. H. Kostohryz, H. V. Krasyl'nykova, Monitoring the quality of the educational process in a higher education institution: a monograph, Khmel'nyts'kyy, Ukrayina: KHNU, 2009. (in Ukrainian).

[19] V. P. Serhiyenko, N. V. Sorokina, «Theoretical and methodological foundations of monitoring the quality of higher education», Zbirnyk naukovykh prats' Kam 'yanets'-Podil's 'koho natsional'noho universytetu im. Ivana Ohiyenka. Ser.: Pedahohichna, vyp. 19, pp. 119-124, 2013. [Online]. Available: http://nbuv.gov.ua/UJRN/znpkp_ped_2013_19_44. Accessed on: Nov. 04, 2019. (in Ukrainian).

[20] L. A. Martseva, «Testing as a Factor in the Formation of Professionally Important Qualities of Future Specialists», Naukovyy chasopys Natsional'noho pedahohichnoho universytetu imeni M. P. Drahomanova. Seriya 5: Pedahohichni nauky : realiyi ta perspektyvy : zb. nauk. Prats', vyp. 43, pp. 131-138, 2013. (in Ukrainian).

[21] V. A. Mizyuk, O. V. Kovalenko, «On One Approach to Computer Testing of Student Achievement», Naukovyy visnyk Izmayil's 'koho derzhavnoho humanitarnoho universytetu. Seriya: Pedahohichni nauky, vyp. 33, s. 120-125. [Online]. Available: http://dspace.idgu.edu.ua/jspui/bitstream/123456789/210/1/28.pdf. Accessed on: Nov. 04, 2019. (in Ukrainian).

[22] S. O. Mudruk, Standardized Educational Measurements 2018 in Higher Legal Education. Single Professional Entrance Test and Single Entrance Exam. Analytical Research, Kyyiv, Ukrayina: Vaite, 2019. [Online]. Available: https://www.osce.org/uk/project-coordinator-in-ukraine/422930?download=true. Accessed on: Nov. 04, 2019. (in Ukrainian).

[23] O. M. Yurkevych, Zh. O. Pavlenko, H.V. Kovalenko, «Database of Practical Logic: Training of Intellectual Abilities», Certificate of copyright registration for the work No. 73545, Ser. 22, 2017 [Online]. Available: http://dl.nlu.edu.ua/course/view.php?id=34. Accessed on: Nov. 04, 2019. (in Ukrainian).

This work is licensed under Creative Commons Attribution-NonCommercial-ShareAlike 4.0 International License. 